\title{
Towards a structure of feeling: abjection and allegories of disease in science fiction 'mutation' films
}

\author{
Frances Pheasant-Kelly
}

\section{Correspondence to} Dr Frances Pheasant-Kelly, School of Media, Faculty of Arts, George Wallis Building, University of Wolverhampton, Molineux Street,

Wolverhampton WV1 1DT, UK f.e.pheasant-kelly@wlv.ac.uk

Accepted 11 July 2016 Published Online First 10 August 2016

\section{ABSTRACT}

This article considers differences between the representation of mutation in science fiction films from the 1950s and the present, and identifies distinctive changes over this time period, both in relation to the narrative causes of genetic disruption and in the aesthetics of its visual display. Discerning an increasingly abject quality to science fiction mutations from the 1970s onwards - as a progressive tendency to view the physically opened body, one that has a seemingly fluid interior-exterior reversal, or one that is almost beyond recognition as humanoid-the article connects a propensity for disgust to the corresponding socio-cultural and political zeitgeist. Specifically, it suggests that such imagery is tied to a more expansive 'structure of feeling', proposed by Raymond Williams and emergent since the 1970s, but gathering momentum in later decades, that reflects an 'opening up' of society in all its visual, sociocultural and political configurations. Expressly, it parallels a change from a repressive, patriarchal society that constructed medicine as infallible and male doctors as omnipotent to one that is generally more liberated, transparent and equitable. Engaging theoretically with the concept of a 'structure of feeling', and critically with scientific, cinematic and cultural discourses, two post1970s' 'mutation' films, The Fly (1986) and District 9 (2009), are considered in relation to their pre-1970s' predecessors, and their aesthetics related to the perceptions and articulations of the medical profession at their respective historic moments, locating such instances within a broader medico-political canvas.

\section{INTRODUCTION}

Since the 1970s, there has been a turn to the abject body in visual culture that is particularly noticeable in science fiction films concerning mutation but also extends from conceptual artworks through to other cinematic genres, television stylistics ${ }^{1}$ and television content. In his article 'The turn of the body', Roger Cooter $^{2}$ likewise discerns a somatic trend during the latter decades of the twentieth century though contends that "there exist[s] no across-the-board account of how intellectuals came to engage with the body [at this time]" (p. 394). Even though Cooter acknowledges a connection between politics, biomedicine, visual culture and equal rights, he pursues his argument through a focus on the body in historical scholarship. In a related vein, Screen journal presented a special issue on body horror in 1986, in which Philip Brophy ${ }^{3}$ refers to the "graphic sense of physicality" of certain horror films, as well as a "mode of showing as opposed to telling [original emphasis]" (p. 8). In the same issue,
Pete Boss ${ }^{4}$ focuses on cinema of the time that was informed by images of medicine, including "transplant surgery, Medicare expenses, iatrogenic illness, malpractice and the problem of legally-defined death" (p. 22), and relates these to "the horror films' unquestionable obsession with the physical constitution and destruction of the human body" (p. 15). Both articles connect biological horror with contemporaneous real-world medicine and science, but their arguments at the time were founded on an incomplete picture. Retrospectively, one might now suggest that the two scholars began to identify an unfolding trend in film that expressed a broader shift in thinking. Even though it is not possible to correlate unequivocally a genre's aesthetics with either generalised attitudes towards medicine or with broader cultural emotions, there is nonetheless a continuity between the onset of abject aesthetics in post-1970s' science fiction and the questioning of institutions such as medicine. This correlation is rooted in what Raymond Williams ${ }^{5}$ describes as society's "felt sense of the quality of life at a particular place and time" (p. 68). The central contention here is that such imagery may be viewed through the lens of a more expansive 'structure of feeling, emergent since the 1970 s, but gathering momentum in recent decades, that reflects an 'opening up' of society in all its visual, socio-cultural and political configurations. Expressly, the materialisation of body imagery parallels a change from a repressive, patriarchal society that constructed medicine as infallible and male doctors as omnipotent to one that is generally more liberated, transparent and equitable. Specifically, this article focuses on abject aesthetics with reference to mutation films as case studies, relevant because of their horrific visuals, but also because they draw on scientific premises of genetic manipulation and contagion. Mutation films illustrating the onset of abject imagery since the 1970s abound and examples include Eraserhead, ${ }^{6}$ Rabid, ${ }^{7}$ The Incredible Melting Man, ${ }^{8}$ Alien (and its sequels), ${ }^{9}$ The Brood, ${ }^{10}$ Altered States, ${ }^{11}$ Contamination, ${ }^{12}$ The Thing, ${ }^{13}$ Prometheus ${ }^{14}$ and, also examined here, District $9^{15}$ and The Fly. ${ }^{16}$ In comparison, pre-1970s' mutation narratives such as The Incredible Shrinking Man ${ }^{17}$ and the original 1958 version of The Fly ${ }^{18}$ are 'clean' and avoid any suggestion of corporeal deterioration or decay. Rather, Neumann's The Fly ${ }^{18}$ involves the anatomical transposition of a fly's head and claw onto a human body, this physical change focusing on the blackness and fur-like texture of the 'fly's' head rather than abject bodily fluids, and likely reflecting the racial politics of the time. In line with its zeitgeist 
of nuclear weapons' development and testing, a theme of atomic structures also pervades the film, as opposed to the genetic and somatic sensibilities of the 1986 remake. Moreover, the disfigurements of the hybridised scientist are only intermittently discernible, his gigantic fly's head being cloaked by a black cloth, and his claw-like 'hand' hidden in a pocket (a detail upon which the later District $9^{15}$ draws intertextually). When visible, these are generally viewed in long shot or medium shot in contrast to the extended close-up sequences that dwell on abject qualities in Cronenberg's later version. In a similar vein, the mise-en-scène tends to be much more clinical and technological than in Cronenberg's production and is typified by the transportation pods, which are rectangular in the 1958 film, but are uterineshaped in the 1986 version. Furthermore, because of the intense light emitted during the teleportation process, the scientist and his wife wear goggles, the entire procedure being reminiscent of nuclear testing of the time. Together with the backdrop of mechanised whirring and clicking sound effects, the overall effect is one of technology rather than viscerality.

Conversely, Cronenberg's remake of The Fly, ${ }^{16}$ in line with other post-1970s' science fiction mutation films, has a pervasive sense of fluidity, disgust, infiltration and physical decomposition, its marked visual contrast with its predecessor providing an indication of the shift towards corporeality. These abject tropes are even more prominent in the later film, District $9,{ }^{15}$ which, similar to The Fly, ${ }^{16}$ allegorises contagion and critiques a range of scientific practices. Indeed, it draws intertextually on both versions of The Fly. ${ }^{16}{ }^{18}$ Given that District $9^{15}$ and Cronenberg's The Fly $y^{16}$ each reflect their respective contemporaneous medical landscapes through mutation narratives, and are chronologically distant but intertextually connected, this article discusses the two films to illustrate the bodily turn in terms of Williams' concept of 'a structure of feeling, ${ }^{5}$

\section{STRUCTURE OF FEELING}

As noted, this 'structure of feeling' is not restricted to either the media industries or the medical profession but is a mood or way of thinking discernible retrospectively across the entire sociocultural and political spectrum at any given moment. Ian Buchanan ${ }^{19}$ highlights both the retrospective and indeterminate aspects of the concept, explaining that the term

\begin{abstract}
refers to the different ways of thinking vying to emerge at any one time in history. It appears in the gap between the official discourse of policy and regulations, the popular response to official discourse and its appropriation in literary and other cultural texts. Williams uses the term feeling rather than thought to signal that what is at stake may not yet be articulated in a fully workedout form, but has rather to be inferred by reading between the lines. If the term is vague it is because it is used to name something that can really only be regarded as a trajectory. (p. 455)
\end{abstract}

This trajectory, as Williams ${ }^{20}$ states, extends from "a particular work, through its particular form, to its recognition as a general form, and then the relation of this general form to a period" (p. 9). Looking back, as outlined by Boss ${ }^{4}$ the British/US landscape featured specifically, a patriarchal system of medicine that embraced a 'club culture"21 and gender disparity in terms of both pay and employment figures; ${ }^{22}$ the prominence of iatrogenic disease, for example, hepatitis $\mathrm{C}$ and Creutzfeldt-Jakob disease from contaminated blood and growth hormone products; an emerging failure of medicine to combat infectious pathogens, notably HIV/AIDS; medical controversies such as the body parts scandal at Alder Hey Hospital in the UK, when patients' organs were stored without consent; and a change in the tide of public opinion not only towards medicine but also in recent times towards other entrenched institutions and associated cover-ups.

\section{ABJECTION AND BODY HORROR}

Organisations currently undergoing transformation and heightened accountability range from the Catholic Church and banking systems to the BBC, as well as a number of UK police forces, for reasons akin to those affecting the National Health Service and the medical profession in general, namely institutionalised discrimination, unethical/illegal practices, corruption and negligence. Alongside the investigation and regulation of such institutions, a corresponding change has been inscribed onto the physical body in visual culture, with a particular focus on abject and previously concealed or taboo forms. These instances of disgust, corporeality and physical deterioration are theorised by Julia Kristeva ${ }^{23}$ as sources of abjection. While Kristeva ${ }^{23}$ relates the abject predominantly to the feminine/maternal body, an aspect that might be especially typified by the grotesque birth scenes common to many science fiction films, including, for example, those in Alien Resurrection ${ }^{24}$ and The Fly, ${ }^{16}$ the concept extends beyond these parameters. Her account of policing abjection primarily centres on maintaining the physical integrity of the body, and therefore, even though both of the aforementioned films involve or symbolise abnormal 'birth', they are also abject because, as mutation narratives, they are connected to modes of somatic deterioration that derive from bodily infiltration at the cellular level. The preoccupation with bodily interiors and leakage of contaminating bodily fluids typically found in such biological horror constitutes a further element of the abject. Also fundamental is one's physical reaction upon encountering the corpse, which Kristeva ${ }^{23}$ considers the utmost in abjection (p. 3). Yet, Kristeva's analysis does have a broader conceptual basis, moving beyond the body's physical reactions to include such transgressions as immorality and xenophobia, as well as describing various neurotic and psychotic states. As noted, a significant aspect of her theory derives from the recognition, formation and maintenance of boundaries. However, while she discusses these predominantly in bodily terms, her model also involves social and psychological aspects that are essential to developing and retaining a coherent social identity. In fact, the integrity of one's (physical and social) identity is crucially implicated in keeping the abject at bay and any contravention that "disturbs identity, system, order" and "does not respect borders, positions, rules" is consequently liable to abjection (p. 4).

Accordingly, as theorised by Barbara Creed, ${ }^{25}$ the horror film is an obvious place to encounter the abject, first, because the identity of its characters is often compromised, as is evident in hybrids such as the vampire, werewolf and zombie; and second, because bodily fluids and boundary transgression feature significantly. Such motifs are especially apparent where these hybrids are scientifically instigated (the monster of Branagh's Mary Shelley's Frankenstein, ${ }^{26}$ for instance, has distinctly abject qualities). Certainly, scenes of extreme blood loss and dismemberment, often described as 'body horror', are characteristic of the slasher film, a subgenre of horror that also developed in the 1970 s, and that relates to the mutation film in its fascination with, and displays of repulsive imagery. Ronald Cruz, ${ }^{27}$ however, differentiates 'slasher' body horror from those films that are biologically motivated and to which he assigns the term 'biological horror' (though he includes zombie films here). Yet, even if typical slasher 'body horror' lacks an obvious scientific foregrounding, and its cinematography characteristically presents rapidly edited sequences to provoke fright, there are 
instances where, similar to the mutation film, it too lingers over grotesque imagery through the use of slow pans. However, because of censorship problems, scenes involving the infliction of violence are less likely to be subjected to extended close-ups and protracted pans than the freak-show visuals of the mutation film. One such example of the latter arises in the opening scenes of Alien Resurrection. ${ }^{24}$ Here, the camera scans over a pulsating, amorphous mass, the spectator unsure exactly of its nature, until a distorted single eye comes into view, followed by images of other organs embedded within it. Later in the film, extended pans languish over gigantic glass vessels containing fully grown, grotesque experimental clones of protagonist, Ellen Ripley (Sigourney Weaver). If Jackie Stacey ${ }^{28}$ sees Alien Resurrection ${ }^{24}$ as concerned with genetic engineering (p. 36), the film lies on a continuum with other abject imagery arising from the $1970 \mathrm{~s}$ and, it is argued here, is reflective of broader anxieties about medicine. This is not to say that the aesthetics of interiority characteristic of biological horror pre-empted changes in the real scientific world, or indeed, the reverse. Rather, the fields of medicine and visual culture mutually influenced each other over time, both directly and intertextually. For instance, the aforementioned UK 'body parts' controversy concerning illicit organ storage at Alder Hey Hospital partly came to light because a sculptor was found to be acquiring human cadavers from hospitals for artistic purposes, although the use of human tissue for creative arts extended beyond this case. ${ }^{29}$

The reasons for differences between pre-1970s' and post-1970s' mutation films are potentially manifold, with one obvious explanation being an overall relaxation of censorship/ classification criteria since the 1950s. Certainly, the Motion Picture Association of America (MPAA) underwent a change in presidency in 1966 and, as a result, the Motion Picture Production Code, which had already begun to weaken, was phased out altogether. It was replaced by a rating system in 1968, which, as Thompson and Bordwell ${ }^{30}$ note, "allowed the industry to present itself as being sensitive to public concern while giving filmmakers license to treat violence, sexuality, or unorthodox ideas" (p. 515). Refinements in technology may also influence such depictions since digital imagery enables a more credible portrayal of genetically instigated monstrosity. As Stace $^{28}$ describes, this is evident in the previously noted opening sequence of Alien Resurrection ${ }^{24}$ in which the "extended spectacle of cell mutation uses digital special effects to foreshadow the horrors of genetic engineering, a form of scientific intervention into cellular life that threatens to produce monsters as well as marvels" (p. 40). While digital technologies have undeniably facilitated the turn to the abject body, I would argue that the advent of MRI and CT scanning during the 1970s, along with more sophisticated endoscopes, has had an equally profound impact on mutation film aesthetics. Specifically, the ability to visualise the interior body as a kinetic living entity (rather than as the fixed imagery of the X-ray) seems more relevant not only in explaining the aesthetics of the opening scene in Alien Resurrection ${ }^{24}$ but also to the preoccupation with bodily interiors in all visual arts and media. So too has the Human Genome Project (1990-2003) brought analysis of genetic matter to the forefront of societal consciousness.

\section{WOUND CULTURE AND THE BODILY TURN}

A further contributory factor involves societal acclimatisation in that exposure to media portrayals over time socialises audiences to norms, attitudes and values accommodating such imagery. Within this acclimatisation lies a move to what Mark Seltzer ${ }^{31}$ describes as 'a wound culture', which he explains as "the public fascination with torn and opened bodies and torn and opened persons, a collective gathering around shock, trauma, and the wound" (p. 4). Typical examples of such wound culture are forensic crime dramas including Silent Witness, ${ }^{32}$ CSI: Crime Scene Investigation (and its spin-offs), ${ }^{33}$ and Waking the Dead, ${ }^{34}$ and, more recently, Scandinavian productions such as The Bridge ${ }^{35}$ and The Killing. ${ }^{36}$ Previous US and UK medical dramas such as ER, ${ }^{37}$ Bodies $^{38}$ and Cardiac Arrest ${ }^{39}$ too contained explicit scenes of bodily abjection, leading Seltzer ${ }^{31}$ to describe ER as "pure wound culture" (p. 19). These medical dramas also exhibited a pattern of change consistent with real medical institutions and whereas earlier ones presented the figure of the inevitably male doctor as a kindly life-saver or handsome hero in fictional series such as Marcus Welby $M D^{40}$ and Dr Kildare, ${ }^{41}$ later portrayals, including those of $\mathrm{MASH}^{42}$ and St Elsewhere, ${ }^{43}$ shifted to accommodate the image of the on-screen doctor as professional but progressively more fallible and not always able to save lives. Concurrently, more sinister cinematic depictions surfaced, including, for example, the organ-trader doctor, George Harris (Richard Widmark) of the science fiction film, Coma. ${ }^{44}$ By the 1990s, the medical officers of $E R^{37}$ and Chicago Hope $e^{45}$ were increasingly female, ethnic, homosexual and disabled. Notwithstanding the earlier influences of $M A S H^{42}$ and St. Elsewhere, ${ }^{43}$ many medical dramas took their cue from the aesthetically groundbreaking $E R^{37}$ in which unique modes of filming (such as extreme overhead shots of abject scenes interjected by frenetic Steadicam camerawork) facilitated technologically a visual laying bare of medical procedures and patient deaths that correlated with the unfolding peri-millennial climate of candour and transparency.

The turn to corporeality also manifested in national and international postmodern artworks during the period from the 1970 s onwards, which, as Walker ${ }^{46}$ notes, was an interim period that saw the mood change from one of optimism to pessimism and whose art was characterised by a "repoliticization and feminization" (p. 2). Examples include Andres Serrano's photographic series of corpses, entitled The Morgue, ${ }^{47}$ and Gunther Von Hagens' Body Worlds exhibition, ${ }^{48}$ which featured 'plastinated' cadavers (a preservation technique developed by Von Hagens), while 2002 saw the first public autopsy for 170 years. So too is the exposure of physical interiority rendered in works such as Mona Hatoum's video installation Corps Étranger $^{49}$ and Damien Hirst's dissected Mother and Child Divided. ${ }^{50}$ Recent incarnations of bodily explicitness may be seen in British medical reality programming, for example, Embarrassing Bodies, ${ }^{51}$ which deals with the doctor-patient relationship through addressing the taboos of the body. Clearly, therefore, the turn to the abject witnessed in mutation films is not merely a reflection of developments in the horror genre or ameliorative changes in British Board of Film Classification (BBFC)/MPAA classification, but suggests a more holistic, chronologically broadened, contextual paradigm.

\section{AIDS AND THE MEDICAL LANDSCAPE}

Typifying the relationship between the mutation film, the bodily turn and the medical landscape are The Fly ${ }^{16}$ and District 9. ${ }^{15}$ As well as each addressing the risks of genetic manipulation, and the latter, the inequalities of apartheid (it is set in South Africa), they deal allegorically with contagion and its accompanying disfigurement. Expressly, given the timing of The Fly's release during the early years of the AIDS crisis, and the fact that South Africa is itself in the 'midst of a catastrophic AIDS epidemic',52 one might read this contagion as HIV. There are some cautionary aspects to take into account in drawing 
such conclusions, namely, as Ernest Mathijs ${ }^{53}$ notes, that Cronenberg's films made prior to the AIDS epidemic are also informed by disease and contamination. As further revealed by Mathijs, Cronenberg states that he did not consciously relate the film to AIDS. Even so, a retrospective analysis of the relationship between science, science fiction and the films' socio-cultural contexts cannot avoid the fact that AIDS was a mainstream media item in the USA at exactly the time of The Fly's ${ }^{16}$ release. Moreover, Susan Sontag ${ }^{54}$ suggests that HIV has mutative connotations, and notes "the potential of AIDS as a metaphor for contamination and mutation [because] [v]iruses are not simply agents of infection, contamination. They transport genetic 'information', they transform cells" (pp. 153-154). The AIDS metaphor is especially relevant to an argument for a revised 'structure of feeling' developing in the 1970s because it embodied the crisis in Western medicine-which had previously kept major disease outbreaks under control—namely its failure to deal with new pathogens. In this respect, Sontag ${ }^{54}$ indicates the medico-political implications of a seemingly incurable disease, stating that

\begin{abstract}
AIDS marks a turning point in current attitudes towards illness and medicine, as well as toward sexuality and toward catastrophe [...] The emergence of a new epidemic disease, when for several decades it had been confidently assumed that such calamities belonged in the past, has inevitably changed the status of medicine. The advent of AIDS has made it clear that the infectious diseases are far from conquered. (p. 158)
\end{abstract}

In sum, the failure to achieve a cure for AIDS began to confirm suspicions about the fallibility of medicine and contributed to an unfolding turnaround in public feeling that interrogated discrepancies within the healthcare professions and the previous unquestioned status of doctors. As Allan Brandt and Martha Gardner ${ }^{55}$ suggest, "the emergence of the AIDS pandemic was viewed by many as a powerful indicator of the end of 'the golden age of medicine"' (p. 33). They further comment that

by the 1970s and 1980s, many had identified a crisis in trust and authority in doctor-patient relationships. Doctors and patients had become 'strangers' in highly bureaucratised and impersonal institutions. The very technologies celebrated at the height of the 'golden age' now became symbolic of the sterile, technocentric nature of modern health care. Indeed, the paradox that lifesaving technologies could extend life indeterminately led to fears of comatose and vegetative patients being tethered to machines sometimes only for the purpose of having organs harvested for transplantation. (p. 32)

If this climate had been fostered by a distancing between doctors and patients and gender inequalities within the medical profession, it also flourished in the wake of a number of controversies that came to light. As Jason Jacobs ${ }^{56}$ states, "[i]t is clear that a post-war optimism in science, medicine and progress has been transformed into a widespread cynicism and suspicion of the medical industry, from drug companies to surgeons to the 'insensitive' local GP" (p. 41). US medicine was affected by similar discrimination, both at the level of treatment, whereby, as Jacobs ${ }^{56}$ notes, "in 200040 million US citizens did not have medical insurance at all" (p. 43), and at the level of employment of medical staff (doctors were mostly white and male). In this respect, Rosemary Pringle ${ }^{57}$ reports that only $10 \%$ of doctors in 1982 in the USA were women and suggests that "The wealth and prestige of American medicine is associated with the fact not only that it is private but also it has largely been the monopoly of men" (p. 4). Indeed, Jacobs further comments that "[w] hile the US healthcare context is different it also had to face the various critiques of medical science and practice from the 1970s onwards. There was a critique of medical macho culture and a growing suspicion of medical science's claims of progress towards a healthier [and therefore better] society" (p. 43). Pringle $^{57}$ gestures towards a structure of feeling when she states that "while medical discoveries continue at a rapid rate, the mood has changed" (p. 7) and relates this mood specifically to gender, stating "[b]oth medicine and modernity have been linked with masculine power and domination. The reversals to medical triumphs can be seen as a colossal blow to the masculine ego. Women have to some extent caused the 'trouble' in attacking patriarchal medicine [...] [b]ut they can also be represented as part of the solution, the new 'human' face of a humbler form of medical practice" (p. 7). If US medicine had its failures, the realisation of a flawed institution resonated more profoundly in the UK where there were accounts of storage of, and unauthorised research on, body parts, as well as medical neglect, and of doctors 'playing god' in previous decades. In this respect, Dixon-Woods et al ${ }^{21}$ identify a model of collegial self-regulation within the British medical profession that "created the conditions for transgressions by doctors to be tolerated" (p. 1452). Examples include numerous high-profile controversies of the 1990s, initiated in 1998 by the aforementioned theft of body parts for artistic purposes by sculptor, Anthony Kelly. ${ }^{29}$ Thereafter followed a Public Inquiry into the 'Bristol baby hearts' scandal when cardiac surgeons James Wisheart and Janardan Dhasmana caused the unnecessary deaths of 30 infants from 1984 to 1995 by continuing to operate on them despite an unacceptably high failure rate $; 1$ and the body parts controversy at Alder Hey Hospital in 1999, when body organs were harvested for research, partly for financial gain whereby children's organs were sold for profit. ${ }^{29}$ i In addition, Squier ${ }^{29}$ reports that "an 'archive' of human and fetal organs had been discovered at the Alder Hey Hospital, including a heart collection containing more than two thousand hearts; a fetal collection containing around 1500 fetuses, and an additional collection that by December 1999 had accumulated more than 445 partial or full fetal remains" (p. 175). Alder Hey, however, was not the sole institution involved in organ storage. It was a widespread and accepted practice, and in several hospitals where I worked from the 1970s to the 1990s, preserved body parts and entire foetuses were regularly on display. In fact, the above-mentioned scene of grotesque 'foetal' mutations in Alien Resurrection ${ }^{24}$ recalls many of these freak-show 'curiosities' stored in pathology laboratories before the body parts embargo of the 1990s. All UK hospitals were subsequently screened and employees' belongings were searched physically for body parts. The legislative outcome of these controversies was the Human Tissue Act 2004, which criminalised unauthorised human tissue storage. ${ }^{\text {ii }}$

Alongside these incidents occurred other high-profile cases of medical misconduct and negligence, although many had been covered up in previous years in what Dixon-Woods et $a l^{21}$ refer to as the 'club culture' (p. 1457) of medicine. They included the Shipman case in which GP Harold Shipman murdered hundreds of his patients, along with several other cases. ${ }^{21} \mathrm{~A}$ public

${ }^{i}$ The science fiction film Coma $^{44}$ seems to anticipate this scenario because it similarly involves the storage of human cadavers for illicit organ trading.

iiSee http://www.hta.gov.uk/legislationpoliciesandcodesofpractice/ codesofpractice.cfm 
loss of confidence was compounded even further by medical scandals such as that concerning the Kent and Canterbury Hospitals NHS Trust where a failure in cervical screening standards "led to 90000 women having samples re-examined, of which 47 received compensation for misdiagnosis". ${ }^{58}$ Such incidents prompted the regulation and move to transparency in medical institutions along with the dismantling of hierarchies that had been previously male-dominated and patriarchal. Dixon-Woods et $a l^{21}$ suggest that the imposition of a new regulatory framework occurred not only as a result of these controversies (because there had been many before and no action had been taken previously), but because of the intersection of a particular set of circumstances "that created an unstoppable imperative for reform" (p. 1452). Specifically, Dixon-Woods et al ${ }^{21}$ argue that it was the extreme nature of these scandals and the fact that they occurred one after another in rapid succession, along with "vivid, emotional rhetoric in reporting" (p. 1456). In addition, public attitudes towards medicine had changed, leading to a "destruction of deference [...] and the decline of professional authority. These changes at a societal level were evidenced by a remarkable increase in the ability of the lay public to have its demands for reform taken seriously once the transgressions were publicised". ${ }^{21}$ Concurrently, the action to eradicate patriarchal hierarchies was further promoted by equal rights legislation and the recognition that certain female-dominated professions allied to medicine, previously ranked beneath those of male-dominated professions, had an equal status. The overall effect was to reduce discrimination against women, ethnic minorities and those with physical differences that had resulted from previous bias, cover-ups and 'jobs for the boys'.

\section{CONTAGION, THE FLY AND DISTRICT 9}

Although AIDS became an integral part of the newly exposed failings of the medical landscape, its details too were initially repressed. As Paula Treichler ${ }^{59}$ reports, in the USA "no comprehensive, coordinated national plan for AIDS media education has ever been put in place [...] More directly responsible was the 1980 election of President Ronald Reagan and his conservative administration together with the rise of the far right and Christian conservatism; continuing attacks on secular institutions like the Centers for Disease Control and Prevention crippled AIDS prevention efforts from the beginning" (p. 94). The flaws of this landscape concerned not only the way in which the outbreak was not addressed early on, but also in the inability to effect a cure. The stigma attached to AIDS, which had been fuelled by media reports employing terms such as 'gay plague' and 'gay cancer', hampered voluntary HIV antibody testing and counselling and was especially the case in South Africa. $^{52}$ Indeed, the intimation of HIV in The Fly ${ }^{16}$ and District $9^{15}$ lies in the manner that both protagonists, who both accidentally undergo mutation, are stigmatised and become social outcasts. The equation between HIV and their respective mutations is further suggested in the high visibility and/or abject nature of their infection (particularly skin rashes and blisters, vomiting, diarrhoea and hair loss), ${ }^{\mathrm{iii}}$ and gross bodily transformations that gradually subvert the exterior-interior binary. In each situations, mutation involves genetic fusion with another 'species', in one case, a housefly (inherently associated with dirt), and in the other, the alien beings of District $9 .{ }^{15}$ One finds a clue to an allegory of contagion in South Africa's history

${ }^{\text {iii See Fife and Wright }}{ }^{60}$ for a comprehensive list of typical symptoms. that charts catastrophic levels of HIV infection. Film scholar Edward Guerrero $^{61}$ also formulates a link between The Fly ${ }^{16}$ and AIDS through the protagonist's many sexual encounters, which he suggests are excessive for a horror movie, as well as Brundle's bodily deterioration and commentary about infectious disease. Taking into account the previously mentioned cautions, it is not difficult to understand why The Fly ${ }^{16}$ should be readily interpreted in this way. The film opens with an out-of-focus scene that causes it to appear as if a microscope image of writhing bacteria is in view but as the camera pulls focus it becomes evident that the 'bacteria' are, in fact, human individuals attending a conference. Here, scientist Seth Brundle (Jeff Goldblum) discusses his new discovery of teleportation with journalist Veronica Quaife (Geena Davis) and describes it as 'one that will change the world as we know it'. The teleportation devices, however, are not wholly functional and Brundle is unable to teleport animate objects, verified when we see an unsuccessful experiment on a baboon. A close-up of the teleported primate reveals that it is flayed but still alive, and Brundle explains that the experiment 'turned the baboon inside out'. This differs from the original version of The Fly ${ }^{18}$ when, instead of the flayed baboon, a teleported pet cat completely disappears and only its haunting disembodied screams remain as it is transformed into 'a stream of cat atoms travelling through space'. ${ }^{18}$ While illustrating the abject aesthetics of the post-1970s' science fiction film, the baboon sequence (like District 9) draws attention to issues of vivisection, which was another area of particular concern in medical testing of that era. A further error occurs when Brundle later attempts to teleport himself, unaware of a housefly in the pod. When Veronica returns, his outward appearance seems to be normal, though almost immediately there are signs of personality change: his senses become sharpened and his mental capacity seems heightened. Other inexplicable changes include an excessive craving for sugar, while a close-up of his shoulder reveals strange, black hairs growing from a small wound. Thereafter, he appears physically enhanced too and long shots disclose him performing incredible feats of strength on a gymnastics bar. More relevant to Guerrero's ${ }^{61}$ claim for an allegory of AIDS, he also becomes sexually voracious and it is during one such episode with Veronica that she notices that the coarse black hairs growing from his shoulder wound are more prominent. Subsequently, Brundle becomes aggressive towards Veronica, shouting at her "you only know society's straight line about the flesh! You can't penetrate society's sick grey fear of the flesh", remarks that seem congruent with an analogy of AIDS inflected by a connection with homosexuality. In a further confirmation of a link with sexually transmitted disease, he picks up a prostitute as a result of an arm wrestling contest in which he breaks the man's forearm, the broken bone, framed in close-up, protruding from the bleeding injury. During the encounter with the prostitute, a further rearview shot witnesses the blistering on Brundle's shoulder becoming even more pronounced, the use of directional lighting accentuating its fluidic, abject qualities. Concurrently, his face assumes an increasingly mottled appearance, leading Veronica to tell him that "You must be sick". When he examines his face in the mirror, Brundle becomes aware of his deteriorating appearance and tries to shave the coarse black hairs now growing on his face. In addition, he peels away a fingernail, an action viewed in extreme close-up, and then ejects fluid from his fingertip. In shock, he says "what's happening to me, am I dying?" When Veronica visits him subsequently, Brundle has deteriorated significantly, evidenced by persistent close-ups of his face, which is now covered with suppurating sores and again illuminated to 
emphasise fluid seepage. Even though he has discovered that he has been genetically spliced with a housefly, he tells Veronica that "you're right. I'm diseased and it might be contagious somehow. I wouldn't want to infect you and its accelerating". Further dialogue also seems suggestive of AIDS, including, for example, "I was not pure" and "it mated us, me and the fly". References to a 'bizarre form of cancer', 'lost lymph nodes' and 'hair falling out' are further consistent with AIDS and the associated malignancy, Kaposi's sarcoma. Throughout, images of disgust occur and include a sequence when Brundle suddenly vomits over his food and then touches his ear, which falls off (again, camera close-ups stress the repulsive elements of such events). When Veronica turns to her employer Stathis Borans (John Getz) for advice, he tells her "he's right, it could be contagious. It could turn into an epidemic". Mutation is therefore consistently expressed as an infectious disease. Not only does Brundle's appearance change but his voice also fails the pattern recognition software on his computer, signalling an increasingly incoherent identity consistent with Kristeva's ${ }^{23}$ concept of the abject. His figure movement becomes more erratic, and he twitches involuntarily (thereby assuming the behaviour of a housefly), yet still retains human mannerisms. For example, during a moment of contemplation, he taps a pencil on his teeth. At this point, however, his teeth begin to fall out and he places them in his bathroom cupboard along with an array of other bottled body parts. In the closing sequence, as Brundle drags Veronica towards a telepod with the intention of fusing himself with her, pieces of flesh continually peel away from his face and body, revealing a gigantic insect's head within. Borans manages to release Veronica and the teleportation fuses Brundle with the pod, resulting in a pathetic abject synthesis that has no human semblance whatsoever, except for the pained emotion expressed in its huge eyes. In sum, despite drawing on mutation as a narrative impetus, the film's visuals are inscribed by abject aesthetics that correlate with verbal references to contagion.

District $9^{15}$ follows a similar pattern of bodily deterioration and, at certain points, contains identical sequences to The Fly. ${ }^{16}$ Moreover, its South African-born director, Neill Blomkamp, who relocated to Canada when he was 18, cites the film Alien ${ }^{9}$ as one of his influences. ${ }^{62}$ As well as these intertextual references, it too seems to draw on South Africa's contingent medical controversies, notably its epidemic of AIDS. As Tina Rosenberg ${ }^{63}$ states, "Soon, AIDS in Africa will be doing more than killing millions very year. It will destroy what there is of Africa's economy and cause further instability and, perhaps, war. In the year 2010, the country of South Africa will be almost one-fifth poorer than it would have been had AIDS never existed" (p. 141). The plot concerns the country's infiltration by an alien species, whose spaceship hovers over the city of Johannesburg where it remains for several decades. The South African military police gain entry to the spaceship where they discover hundreds of malnourished creatures, which are then segregated within a razor-wired compound, named District 9. They are subsequently evicted to a more distant location. While the film's focus therefore seems to be on apartheid, as is commonly suggested, ${ }^{64} 65$ it concurrently alludes to anxieties about biomedicine and science akin to those that have beleaguered the UK and US medical profession. Indeed, as Anne-Marie Rafferty ${ }^{66}$ states, "the urgency and complexity of South Africa's historical legacy is in the process of unravelling. Some public hospitals have been plunged into crisis wrought by the need to expand access to services without concomitant increase in resources" (p. 527). This crisis is expressed in the film through scenes of biological horror that articulate more global concerns about scientific scenarios such as stem cell research on embryos, vivisection, experimentation on living beings without consent and the implications of genetic engineering. There are also allusions to contagion and, during documentary-style interviews taking place within the narrative, one interviewee advocates the release of 'a virus, a selective virus, near the aliens'. From these 'interviews', we also learn that the key protagonist, Wikus van de Merwe (Sharlto Copley) (who falls victim to alien mutation), 'did not seem quite kosher' and 'took the choices that were given to him', the overall implication being that he is to blame for his 'illness', a stigma commonly attached to AIDS in the early days of the epidemic. The aliens are represented initially in pejorative ways through camera close-ups that disclose them vomiting and eating cat food, and long shots that show them scavenging through mounds of decaying rubbish. However, this situation is reversed as the film progresses and, indicated by their complete lack of scientific scruples, humans are revealed to be cruel and inhumane. Even though it transpires that the aliens have a sophisticated intelligence far superior to that of humans, they are treated as inferior beings, which might be interpreted as a critique of either racism or negative attitudes towards those affected by AIDS. During the eviction of the aliens from District 9, de Merwe and his team discover an alien egg colony where embryos feed off decaying animals, a sequence again viewed in close-up to accentuate its revolting nature. De Merwe disconnects the embryos from their food source, effectively killing them, and then deploys a flamethrower to incinerate any remaining embryos, the process of 'abortion' viewed by his team with pride and amusement. The film therefore also criticises stem cell experimentation, indicating it as an act of wilful killing. As the film proceeds, the aliens are made more endearing, narratively, by the fact that they show affection towards their families, and visually, by the use of close-ups of them, which, though earlier had tended to assume side-on framing in order to focus on their disgusting facial tentacles and various bodily appendages, now centre on their enormous eyes through frontal framing, thereby exploiting neotenic tropes. ${ }^{67}$ We also realise that they are capable of complex and sophisticated science, creating technology that will enable them to escape. However, the black liquid that will fuel their spaceship also has dire consequences for de Merwe, who confiscates the fuel canister and accidentally sprays its contents over his face. De Merwe then becomes progressively unwell and increasingly physically repulsive to the extent that black fluid leaks from his nose, he regurgitates black vomit and his fingernails peel away, the latter scene being identical to that in The Fly. ${ }^{16}$ The later revelation that the liquid contains alien DNA indicates that his genetic constitution has been compromised (which the film expresses as contagion). The narrative implication of the mutation is that his own DNA, which has combined with alien DNA, enables him to operate alien weaponry (which is engineered to function only in conjunction with alien DNA). As a result, he becomes commercially valuable to the Department of Alien Affairs (which is also a weapons manufacturer), which hunts him down in order to harvest the recombinant DNA from his body tissues. In the hospital, close-ups focus on de Merwe's disfigured hand and, as a doctor cuts away the bloodstained bandages, a huge black claw unfurls, at which point armed officers seal him in a body bag and transport him to another facility by helicopter, reporting that 'we have the infected agent on board'. The camera again cuts to extreme close-ups of de Merwe's disfigured, pustule-covered arm into which scientists insert needles and probes without administering anaesthetic. They also torture him, prodding him with a taser gun at one point to make him 
activate alien weaponry (in order to confirm that his body contains alien DNA) and attempt to dissect him while he is alive and fully conscious. Just as they prepare to dismember his body, one scientist comments, "What happens to him isn't important. What's important is that we harvest from him what we can right now. This body represents billions of dollars worth of biotechnology". The scientists repeatedly talk about infection rather than mutation and discussions concerning the removal and commercial value of de Merwe's body parts- “we need everything, tissue, bone marrow, blood. The procedure's gonna basically strip him down to nothing"-resonate intertextually with the Alder Hey controversy and anxieties over organ donation, especially relevant given South Africa's historical association with cardiac transplant pioneer, Christiaan Bernard. Ironically, his father-in-law (who is in league with the scientists) tells de Merwe's wife that "the doctors are doing their best to save him".

In another sequence, a Nigerian character named Obesandjo (Eugene Khumbanyiwa) also attempts to amputate De Merwe's arm, but for reasons of apparent cannibalism, although Adele $\mathrm{Nel}^{64}$ argues that this is not the case. Rather, $\mathrm{Nel}^{64}$ suggests that "Obesandjo's desire to eat the arm should be contextually associated with the production of muthi [...]. Muthi medicine is an aspect of African holistic healthcare where, among others, human body parts and vital organs are used to make medicine. The harvesting is linked to murder and mutilation" (p. 555). Most significant to the contemporary climate is the film's expression of contagion since, coupled with South Africa's relatively recent history of apartheid, the stigma of the disease and a distinct lack of government action, AIDS has become a dominant force. As Clive Seale ${ }^{68}$ notes, with reference to the work of Gibson, criticisms of a lack of media coverage about AIDS in South Africa suggest that "there have been considerable problems in breaking public taboos concerning discussions of sexuality that have undermined public health efforts to control the spread of the disease [...] In part this may be a legacy of oppression. South African reluctance to promote condom usage [...] may be due to suspicion of the policy, which many believe to have been used by the apartheid regime to try to restrict black population growth" (p. 99). The film's reference to condom use - when one of the Nigerians shows De Merwe a magazine image of his alleged prostitution with an alien and asks him if he was wearing a condom-therefore has a dual connotation. Stuart Allan ${ }^{69}$ points to the plague metaphor commonly employed to describe AIDS in the media at the time of its outbreak, suggesting that "[p]erhaps the most insidious dimension of the plague metaphor was the way in which it contributed to the normalization of an ideological dichotomy between alien, less than human 'others', on the one hand, and everyone else, on the other [...]. In the case of news reporting, the underlying imperatives of this 'us' versus 'them' dichotomy began to cohere as a form of prejudice from the outset" (p. 128). There is clearly a parallel here in District $9,{ }^{15}$ where the 'other' is made distinct as an alien species.

While de Merwe's mutation is depicted physically and verbally as contagion, there are other correlations with disease, specifically the way that he is not only ostracised by his family and friends, but also becomes socially isolated, again resembling the characterisation of Brundle in The Fly. ${ }^{16}$ In their study of AIDS-related stigma and the effect on voluntary testing, Kalichman and Simbayi ${ }^{52}$ report that in a sample of US adults the stigma surrounding AIDS influences their decisions to be tested. They go on to note that "[i]n a South African national survey, $26 \%$ of respondents would not be willing to share a meal with a person living with AIDS, $18 \%$ were unwilling to sleep in the same room with someone with AIDS, and 6\% would not talk to a person they knew to have AIDS" (p. 446). In sum, their findings show similarities between stigma attached to AIDS in the USA and in South Africa, namely that "AIDS related stigmas promote and foster social isolation and discrimination against people with HIV-AIDS" (p. 446). According to Betsy Fife and Eric Wright, ${ }^{60}$ further implications of such stigma include social rejection, financial insecurity and internalised shame (p. 50). They explain that "stigmatized persons lose social status, they are discounted and discredited [...] they are set apart from others, and they are considered to be inferior and to represent a danger to society" (p. 51). For them, when a "stigma is evident to others, persons become labelled as outsiders, [...]. As the individual internalizes this label, it becomes part of his/her identity [which] [...] often results in selfdeprecation and shame" (p. 51). This stigma is played out in District $9^{15}$ when de Merwe tries to buy food at a fast food outlet, just as a news bulletin highlights his escape from an 'isolation unit'. The bulletin states that de Merwe was apprehended after prolonged sexual activity with aliens in District 9. It then describes him as being 'disfigured', 'extremely dangerous' and 'highly contagious', clearly formulating a link between the aliens, sexual activity and disease, consistent with an analogy to AIDS. As a result, he is forced to take shelter in District 9, where he too consumes tinned cat food as he progressively transforms into an alien. At this point, in a further intertextual reference to The Fly, ${ }^{16}$ his teeth fall out and subsequently suppurating sores and wheals appear over his entire torso. Mocke Jansen van Veuren ${ }^{65}$ likewise notes distinct similarities between the abjection played out in District $9^{15}$ and The Fly. ${ }^{16}$ However, Van Veuren ${ }^{65}$ interprets these abject aspects solely from a perspective of apartheid, although one might equally understand District 9's abject aesthetics as concerning AIDS in view of the film's many biomedical references and the fact that South Africa is in the midst of an AIDS crisis.

\section{CONCLUSION}

In sum, the abject/open visuals that emerged in filmmaking, television and postmodern artworks during the 1970s and persist to the present day, and which are typified by The Fly ${ }^{16}$ and District $9,{ }^{15}$ bracket an era in which a 'structure of feeling' concerned with the interrogation/opening up of discriminatory and other undesirable institutional practices intersected with the development of a 'wound culture'. Such uncovering stemmed from radical political shifts and equal rights that occurred during the 1970 s, which journalist Normal Shrapnel ${ }^{70}$ "characterised as the 'decade of the determined minority' because so many minorities demanded recognition and rights" (p. 19). In the course of the same period, AIDS became a prominent global threat and confirmed suspicions about the fallibility of medicine. Delayed action by governments, widespread inequalities in healthcare treatment and employment of medical professionals, together with an extensive catalogue of medical errors and controversies occurring in rapid succession, gave impetus to the need for change. The combination of these diverse factors has arguably engendered an increasingly abject aesthetic across arts, literature and film, the latter made possible because of a relaxation in film censorship. Such a visual style has become especially prominent in the science fiction mutation film and has been encouraged by the digital and medical technologies, including micro-endoscopy, MRI scanning devices and keyhole surgery, which developed during this period. Notwithstanding changes in film censorship, HIV is still off-bounds for 
mainstream film and few productions address it, one exception being Philadelphia. ${ }^{71}$ Even then, a mainstream star Tom Hanks was cast in the leading role, one assumes, to make the protagonist more acceptable to mainstream audiences. Instead, the abject visuals commensurate with the science fiction mutation film have served to accommodate ongoing anxieties about contagious diseases such as AIDS, but are also more recently meaningful in relation to pathogens such as methicillin-resistantstaphylococcus aureus (MRSA) and other antibiotic-resistant infections.

\section{FURTHER READING}

Bates V, Bleakley A, Goodman S, eds. Medicine, health and the arts: approaches to the medical humanities. London and New York: Routledge, 2013.

Bell D. Science, technology and culture. Maidenhead Open University Press, 2006.

Erickson M. Science, culture and society. Cambridge: Polity Press, 2005.

Glasser B. Medicinema: doctors in films. London: Radcliffe Publishing Limited, 2010.

Hallam J. Nursing the image. London: Routledge, 2000.

Harper G, Moor A. Signs of life: medicine and cinema. London: Wallflower Press, 2005.

Kirby D. Lab coats in Hollywood. Cambridge, MA and London: The MIT Press, 2011.

Ostherr 0. Medical visions: producing the patient. New York, USA: Open University Press, 2013.

\section{Competing interests None declared.}

Provenance and peer review Not commissioned; externally peer reviewed.

\section{REFERENCES}

1 Pheasant-Kelly F. Text, image, audience: adaptation and reception of Andrea Newman's Bouquet of Barbed Wire. J Br Cinema Television 2016;13:80-9.

2 Cooter R. The turn of the body: history and the politics of the corporeal. Arbor 2010;186:393-405.

3 Brophy P. Horrality - the textuality of contemporary horror films. Screen 1986:27:2-13

4 Boss P. Vile bodies and bad medicine. Screen 1986;27:14-25.

5 Williams R. The long revolution. Cardigan: Parthian Press, 2011 [1961].

6 Lynch D. Eraserhead. USA 1977.

7 Cronenberg D. Rabid. USA 1977.

8 Sachs W. The Incredible Melting Man. USA 1977.

9 Scott R. Alien. USA/UK 1979.

10 Cronenberg D. The Brood. Canada 1979.

11 Russell K. Altered States. USA 1980.

12 Cozzi L. Contamination. Italy/West Germany 1980.

13 Carpenter J. The Thing. USA 1982.

14 Scott R. Prometheus. USA/UK 2012

15 Blomkamp N. District 9. USA/New Zealand/Canada/UK 2009

16 Cronenberg D. The Fly. USA/UK/Canada 1986.

17 Arnold J. The Incredible Shrinking Man. USA 1957.

18 Neumann K. The Fly. USA 1958.

19 Buchanan I. A dictionary of critical theory. Oxford: Oxford University Press, 2010

20 Williams R. Drama from Ibsen to Brecht. Middlesex and New York: Penguin, 1968.

21 Dixon-Woods $M$, Yeung K, Bosk C. Why is UK medicine no longer a self-regulating profession? The role of scandals involving 'bad apple' doctors. Soc Sci Med 2011;73:1452-9.
22 McManus I, Sproston K. Women in hospital medicine in the United Kingdom: glass ceiling, preference, prejudice or cohort effect? J Epidemiol Community Health 2006;54:10-6.

23 Kristeva J. Powers of horror: an essay in abjection. New York: Columbia University Press, 1982.

24 Jeunet J. Alien Resurrection. USA 1997.

25 Creed B. The monstrous feminine: film, feminism, psychoanalysis. London and New York: Routledge, 1993.

26 Branagh K. Mary Shelley's Frankenstein. USA/Japan 1994.

27 Cruz R. Mutations and metamorphosis: body horror is biological horror. J Popul Film Television 2012;40:160-8.

28 Stacey J. The cinematic life of the gene. Durham and London: Duke University Press, 2010.

29 Squier SM. Liminal lives: imagining the human at the frontiers of medicine. Durham and London: Duke University Press, 2004.

30 Thompson K, Bordwell D. Film history. London and New York: McGraw-Hill, 2003.

31 Seltzer M. Wound culture: trauma in the pathological public sphere. October 1997:80:3-26.

32 McCrery N. Silent Witness. UK 1996-present

33 Zuiker A. CSI: Crime Scene Investigation. USA/Canada 2000-15.

34 Machin B. Waking the Dead. UK 2000-present.

35 Rosenfeldt H. The Bridge. Sweden/Denmark 2011-present.

36 Sveistrup S. The Killing. Denmark 2007-12.

37 Crichton M. ER. USA 1994-2009.

38 Mercurio J. Bodies. UK 2004-06.

39 Mercurio J. Cardiac Arrest. 1994-96.

40 Victor D. Marcus Welby MD. USA 1969-76.

41 Felton N. Dr Kildare. USA 1961-66.

42 Gelbart L. MASH. USA 1972-83.

43 Brand J, Falsey J, Masius J, et al. St Elsewhere. USA 1982-88.

44 Crichton M. Coma. USA 1978.

45 Kelley D. Chicago Hope. USA 1994-2000.

46 Walker J. Left shift: radical art in 1970s' Britain. London and New York: IB Tauris, 2002.

47 Serrano A. The Morgue series. 1992.

48 Von Hagens G. Body Worlds series. 1995.

49 Hatoum M. Corps Étranger. 1994.

50 Hirst D. Mother and Child Divided. 1993.

51 Eglin S, Harris S, Jones D. Embarrassing Bodies. UK 2008-present.

52 Kalichman S, Simbayi L. HIV testing attitudes, AIDS stigma, and voluntary HIV counselling and testing in a black township in Cape Town, South Africa. Sex Transm Infect 2003:79:442-7.

53 Mathijs E. AIDS references in the critical reception of David Cronenberg: 'It may not be such a bad disease after all.' Cinema J 2003:42:29-45.

54 Sontag S. Illness as Metaphor and AIDS and Its Metaphors. London: Penguin, 2002.

55 Brandt A, Gardner M. The Golden Age of Medicine? In: Cooter R, Pickstone J, eds. Companion to medicine in the twentieth century. London and New York: Routledge, 2003:21-37.

56 Jacobs J. Body Trauma TV. London: BFI, 2003.

57 Pringle R. Sex and medicine: gender, power and authority in the medical profession. Cambridge: Cambridge University Press, 1998.

58 Albrow R, Kitchener H, Gupta N, et al. Cervical screening in England: the past, present, and future. Cancer Cytopathol 2012;120:87-96.

59 Treichler P. Medicine, popular culture, and the power of narrative: the HIV/AIDS storyline on General Hospital. In: Reagan L, Tomes N, Treichler P, eds. Medicine's moving pictures: medicine, health and bodies in American film and television. Rochester: Rochester University Press, 2007:93-132.

60 Fife BL, Wright ER. The dimensionality of stigma: a comparison of its impact on the self of persons with HIVIAIDS and cancer. J Health Soc Behav 2000;41:50-67.

61 Guerrero E. AIDS as monster in science fiction film and horror cinema. J Popul Film Television 1990;18:86-93.

62 Desowitz B. Neill Blomkamp Talks District 9. VFXWorld (AWN, Inc.). 14 August 2009

63 Rosenberg T. In: Allan S. Media, risk and science. Buckingham: Open University Press, 2002:141.

64 Nel A. The repugnant appeal of the abject: cityscape and cinematic corporeality in District 9. Crit Art South-North J Cultur Media Stud 2012;26:547-69.

65 Van Veuren M. Tooth and nail: anxious bodies in Neill Blomkamp's District 9. Crit Arts South-North Cultur Media Stud 2012;26:570-86.

66 Rafferty A. Nurses. In: Cooter R, Pickstone J. eds. Companion to medicine in the twentieth century. London and New York: Routledge, 2003:519-29.

67 Stokes D. Things we like: human preferences among similar organisms and implications for conservation. Hum Ecol 2007:35:361-9.

68 Seale C. Media and health. Thousand Oaks, CA and London: Sage, 2002.

69 Allan S. Media, risk and science. Buckingham: Open University Press, 2002.

70 Shrapnel N. In: Walker J. Left shift: radical art in 1970s' Britain. London and New York: IB Tauris, 2002:19.

71 Demme J. Philadelphia. USA 1993. 